\section{0-345 経尿道的前立腺高温度療法の長期成績}

\begin{abstract}
近畿大学 医学部 泌尿器科学教室 ${ }^{\prime \prime}$ 新明会 神原病院 ${ }^{2}$

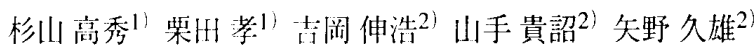

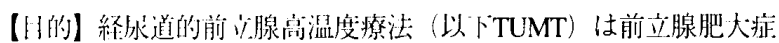
に刘する新しい治旗法として注目されてきた。しかし、本法の有 效性、主期成績については十分な検詂がされていない。今回101 为洌のTUMT治䝤後5年以上の成績をまとめたので報告する。【対

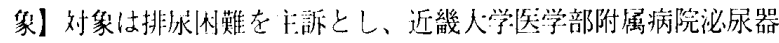
科及び神原病院泌水器科にて前立腺肥大症と診断され、TUMT後5 作以卜経過した101拉例であった。今法は推定重量、最大尿流量 悴、QOL、IPSSスコアー投尗エネルギー青を中心に、1年後、3作 後、5年後の推移を検副した。絬果】排际障害臨床試験ガイドラ インによる全般効果判分:は判定叮能な拝例は65症例 $(64.4 \%)$ で 約斗数が热效であった。101例中15年䦌に21症例（20.8\%）は他手 術追加治療索、13症例（12.9\%）は他疾患に上り死し、2症例 (2.0\%) は前湶湂で治潦の経過をたどった。考察】検討の絬果

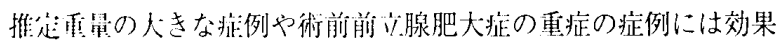
が期徐しにくいように思わ机た。
\end{abstract}

前立腺肥大症 高温度療法 長期成績

\section{O-347 経尿道的前立腺高温度治療における治療無 効症例の検討}

聖フランシスコ病院1)

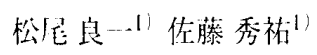

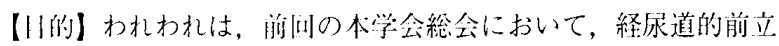

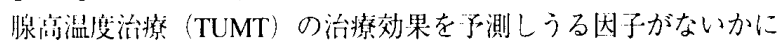
つて報简した，今川は，さらに，TUMTが無効であった症例に つて，その北景因子について検討をくわえた。【対象抢よびう 沚 1996年:4月より1999年10月までに, OLYMPUS社エンドサーム UMWを湖いて，前洞腺肥大壮患者80例にTUMTを施行した，治療

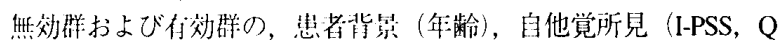

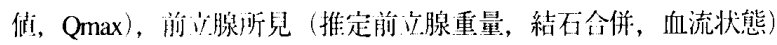
について比較検徍した【結果】全80例の全般有效性は，有効以 1.42.5\%，やや份㕮以 $1.74 .0 \%$ であった. TUMT無效例は18例で,

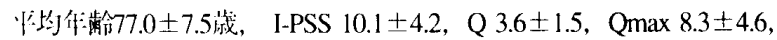

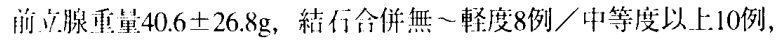
血流不是3例／是好13例であった。これに対し，著効・有効症例31

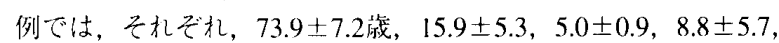
$30.6 \pm 10.8 \mathrm{~g}, 11 / 20$ 例，20/9例であった【結論】备因子とも，

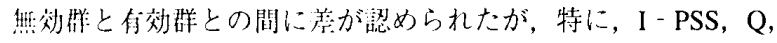

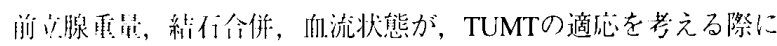
们肺な因子であると考えられた。

経尿道的前立腺高温度治療 TUMT

\section{O-346 経层道的前立腺高温度治療における治療効 果增强因子の検討}

\begin{abstract}
聖フランシスコ病院 ${ }^{11}$
松尾良 - - 1) 佐藤 秀社1)

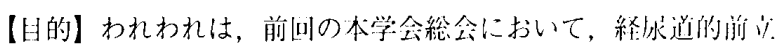
腺高温度治療（TUMT）の治療効果を予測しうる以おがないか心 ついて報告した，今四は，TUMTの洁源条作を変果することによ り，その治療效果を们上させることができないかについて检讨し た、【対象执よび方法】1996华4月より1999华10月までに，当院で TUMTを施行した前立腺肥大成患者のうち，次の放定条作をみた す71例. A群：設定温度 $39.5^{\circ} \mathrm{C}$, 冷却水量 $15 \mathrm{ml} / \mathrm{min}, \mathrm{B}$ 椾 : $39.5^{\circ} \mathrm{C}$,

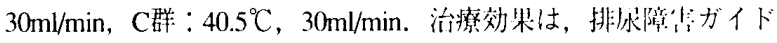

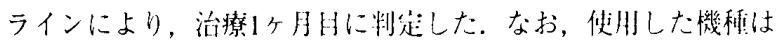
OLYMPUS社エンドサームUMWである。【結果】71例の全般们效 性は，有効以上 $43.7 \%$ ，やや有效以 $1: 74.6 \%$ であった。冬倠の治将 成績は, $\mathrm{A}$ 群 (28例) : 有矨以 $1: 35.7 \%$, やや份效以 $1: 71.4 \%, \mathrm{~B}$ 群（27例）: 有効以上 $55.6 \%$, やや有效以 $1: 81.5 \%$, C排 $(16$ 例）：有效以上 $37.5 \%$, やや有效以 $1.58 .7 \%$ であった【絬渝】 回の検討のなかでは，B群が鼠も洁漝成緹が優れていた。つまり， 冷却水量増加にて治療成績は间上したが，設造温度上多による治 療成績の间上は認められなかった。
\end{abstract}

経尿道的前立腺高温度治療 TUMT

\section{0-348 前立腺組織内レーザー疑固法における経会 陰的前立腺ブロックの効果}

\begin{abstract}
聖マリアンナ医科大学 泌尿器科

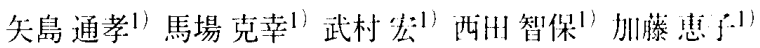
佐々木秀郎”岩本晃明

【目的】私たちは、1998年2月よりIndigo半導体レーザーテ術竖活に

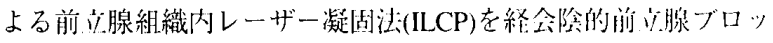
クにて行っている。この麻酔法の效果をけし記人式留洲紙を䏘い て検討したので報告する。【対象とう法】本麻酔法を期いてILCP

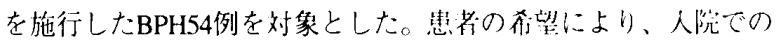

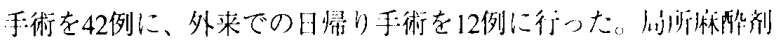
は、1\%塩酸リドカイン注射液と $0.25 \%$ 塩酸ブピバカイン润射液を 行量 1：1で混令し、部約 $30 \mathrm{ml}$ 使用した。会㓌より刺入した22Gの

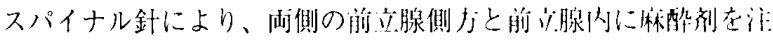

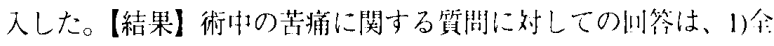
く苦痛は感じなかった：13\%、2)やや苦痛を感じたが、忪分に我 慢できる程度であった：41\%、3)苦痛を感じたが、我慢できる程 度であった：33\%、4)大変苦痛を感し、、我慢するのが椒めてつら， かった：13\%であった。苦痛の種類は、1)瑐み：47\%、2)熟感：

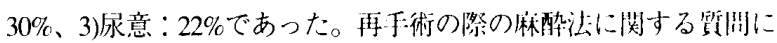

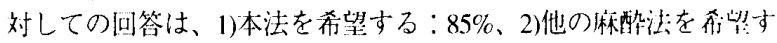
る：15\%であった【結論】日締り手術が增㞦しつつある现代、経 会㓌的前立腺ブロックは、ILCPだけでなく他の内視鏡梌榃・処䍜 にも忘用叮能であり、有用な麻酔法と考える
\end{abstract}

前立腺肥大症 麻酔 経会陰的前立腺ブロック 